\title{
POLITOLANA WICKSTENAE NEW SPECIES, A NEW CIROLANID ISOPOD FROM THE GULF OF MEXICO, AND A REVIEW OF THE “CONILERA GENUS-GROUP” OF BRUCE (1986)
}

\author{
Regina Wetzer, Paul M. Delaney, and Richard C. Brusca' ${ }^{1}$
}

\begin{abstract}
Politolana wickstenae, a new species of cirolanid isopod inhabiting the continental slope $(488-600 \mathrm{~m})$ in the northern Gulf of Mexico is described and figured. The genus now contains 7 species, and is restricted to the north and south Atlantic Ocean. The genus Politolana is redescribed, and a key to 6 genera of Bruce's (1986) "Conilera genus-group" is presented (Conilera, Orphelana, Politolana, Dolicholana, Conilorpheus, Natatolana). Oncilorpheus is herein removed from this group.
\end{abstract}

\section{INTRODUCTION}

In 1985 M.K. Wicksten of Texas A\&M University began a deep-water sampling program utilizing baited traps placed at depths of 400-800 $\mathrm{m}$ in the Gulf of Mexico. Wicksten was interested in recovering live specimens of large benthonic crustaceans, particularly crabs and the giant cirolanid isopod Bathynomus giganteus. Along with these crustaceans, her traps also captured numerous specimens of the new isopod described in this paper. This new species belongs to a genusgroup of Cirolanidae informally recognized by Bruce (1986) and Botosaneanu et al. (1986), and closely corresponding to the "Conilera-group" of Monod (1930). According to Bruce (1986), this genus-group contains 7 genera: Politolana Bruce, 1981; Conilera Leach, 1818; Conilorpheus Stebbing, 1905; Dolicholana Bruce, 1986; Natatolana Bruce, 1981; Oncilorpheus Paul and Menzies, 1971; and Orphelana Bruce, 1981 (Bruce, 1986). Bruce characterized this genus-group by the following features: antennal peduncle articles 3 and 4 subequal in length; pereopod dactyls without a secondary unguis; anterodistal margins of ischium and merus of pereopods IIII produced; abundant long setae on posterior pereopods; no ornamentation on body somites; and frontal lamina usually flat and narrow.

In keeping with terminology currently used in cirolanid systematics, we use the terms "seta/setae" to refer to long, thin, flexible, often ornamented (plumose, etc.), articulated, cuticular processes; and the term "spine" to refer to stout, robust, rigid, unornamented, articulated, cuticular processes. The following abbreviations are used in this paper: LACM,
Los Angeles County Museum of Natural History, Los Angeles, CA; USNM, National Museum of Natural History, Washington, D.C.; SAfM, The South African Museum, Cape Town, South Africa; ZMC, Zoologisk Museum, Copenhagen, Denmark; MCZ, Museum of Comparative Zoology, Harvard University, Cambridge, Massachusetts; BMNH, British Museum (Natural History), London, England; PMS, plumose marginal setae.

\section{SYSTEMATICS \\ Order Isopoda \\ Suborder Flabellifera \\ Family Cirolanidae \\ Politolana Bruce, 1981}

Type Species. Aega polita Stimpson, 1853 (by designation; Bruce, 1981).

Diagnosis. Cirolanidae with short antennules and antennae and large, smooth (unornamented) bodies, 2-6.5 times longer than broad. Eyes often reduced. Pereonite I usually about twice length of pereonite II. Antennule short, peduncle of 4 articles, article 3 longest, article 4 minute. Antenna short, peduncle of 5 articles, articles 1-2 short, 3-5 manifestly longer than 1-2 and progressively longer distally. Frontal lamina usually long and narrow, 2-3 times longer than broad; sessile; clypeus flat. Mouthparts similar to Cirolana. Pereopods IIII “ambulatory." Pereopods I-III ischium and merus produced anterodistally; with long spines and setae. Pereopods IV-VII "natatory"; ischium and merus flattened and broadening distally; all articles generally with long setae. Pleon of 5 free somites, plus pleotelson; pleonite 5 with lateral margins overlapped by 4 . Pleotelson and uropods with marginal spines

1. Invertebrate Zoology Section, Natural History Museum of Los Angeles County, 900 Exposition Boulevard, Los Angeles, California 90007. 
and PMS; uropod peduncle strongly produced medially; lateral (outer) margin of endopod with distal notch; exopod fails to reach endopodal notch, or extends beyond endopodal notch; endopod much broader than exopod. Pleopod rami all with PMS except endopod of pleopod 5; pleopod 1 peduncle about as long as broad; pleopod 1 endopod half as wide as exopod; pleopod 2 of male with appendix masculina arising subbasally and extended slightly past apex of endopod (appendix masculina arises submedially in P. exima, Bruce, in litt.).

REMARKS. Bruce's (1981) original description of Politolana did not include a description of the type species. We have examined types of P. obtusispina (Kensley, 1975) (holotype and paratypes), P. eximia (Hansen, 1890) (syntypes), and $P$. impressa (syntypes), as well as nontype material of $P$. concharum (Stimpson, 1853), P. polita (Stimpson, 1853), and P. micropthalma (Hoek, 1882). The emended diagnosis presented above is based on our examination of this material. In addition, we note the following. Bruce stated that antennal peduncle articles 3-5 are subequal, but judging from his figures, and our examination of specimens, descriptions, and figures of species in this genus, articles 3-5 are progressively longer. Bruce described the peduncle of pleopod 1 as being "as long as broad." However, some variation in this ratio occurs, and in $P$. wickstenae new species the peduncle is slightly wider than long (width $=$ about 1.14 times length). In all cases though, the shape is basically squarish, as opposed to the rectangular shape (width much greater than length) of this article in most cirolanid genera. Bruce described the body as 2-3 times as long as broad, but the type species is about 4 times longer than broad, and $P$. wickstenae is 6-6.5 times longer than broad. Bruce noted that pereonite $I$ is half as long as pereonite II in this genus. This was surely a simple lapsus, as the opposite is actually the case.

Bruce (1981) discussed similarities of Politolana to other genera in the "Conilera genus-group." Whether or not the "Conilera genus-group" (sensu Bruce, 1986) is a natural (monophyletic) group remains to be tested by phylogenetic analysis of the Cirolanidae, a large family containing approximately 45 genera and about 300 species. In any case, Oncilorpheus should not be considered part of the "Conilera genus-group," since it lacks almost all the characters listed by Bruce that define the group (e.g., the ischium of pereopods I-III is not produced on the anterodistal margin, abundant long setae are not present on the posterior pereopods, the frontal lamina is not narrow). Bruce's placement of Oncilorpheus in the "Conilera-group" was based solely on a review of the literature (Bruce, in litt.). The frontal laminae of $\mathrm{Or}$ phelana, Dolicholana, and Conilorpheus also do not fit Bruce's genus-group diagnosis; in Orphelana the lamina is short and triangular, and in the other two genera it is somewhat projecting (see following key). Natatolana and Politolana may be paraphyletic genera, because they seem to have no clearly unique synapomorphies that distinguish them.

Most species in the "Conilera genus-group" have flattened pereopodal articles, and in many cases these articles bear long setae, especially on pereopods V-VII. Such pereopods are typically referred to in the literature as "natatory legs."
However, in many cases it appears that flattening of the leg articles is associated with the development of a concave inner surface, allowing the adjacent distal article to collapse into the more proximal article(s) in a jackknifelike fashion. This arrangement suggests that the pereopods may be folded tightly against the body, perhaps for streamlining when the animal swims.

\section{Key to the Genera of the "Conilera Genus-Group."}

1a. Uropod endopod with notch on lateral (outer) margin; pereopod VII basis without median longitudinal row of setae along outer surface $\ldots \ldots \ldots \ldots \ldots \ldots 2$

b. Uropod endopod without notch on lateral (outer) margin (except Natatolana variguberna); pereopod VII basis with or without row of setae along outer surface .......4 4

2a. Pleopods 1 operculate to all others; pleopod 1 peduncle markedly longer than wide; labrum wider than clypeus Conilera

b. Pleopods 1 not operculate to others; pleopod 1 peduncle width subequal to length; clypeus as wide or wider than labrum

3a. Antennule flagellum shorter than peduncle; frontal lamina small, short, and triangular; body length 2.5-3.0 times width Orphelana

b. Antennule flagellum longer than peduncle; frontal lamina long and narrow; body length 2.0-6.5 times width

Politolana

4a. Endopods of pleopods 3 and 4 without PMS; frontal lamina projects posteroventrally; antennule peduncle article 4 longest Dolicholana

b. Endopods of pleopods 3 and 4 with PMS; frontal lamina not projecting posteroventrally; antennule peduncle article 3 longest, article 4 minute, often partly fused . . 5

5a. Peduncle of pleopod 1 width equal to length; frontal lamina projects anteriorly, wide, and multidentate; pereopods V-VII without median longitudinal row of long setae along outer face, and without cluster of long setae on posterodistal margin ............. Conilorpheus

b. Peduncle of pleopod 1 wider than long; frontal lamina flat, not projecting, narrow, and not multidentate; pereopods V-VII basis with median longitudinal row of long setae along outer face, and with cluster of long setae on posterodistal margin ........... Natatolana

\section{Politolana wickstenae new species}

Material Examined. Holotype (LACM type No. 3008): Nongravid female $24.75 \mathrm{~mm}$ long, NE Gulf of Mexico, $28^{\circ} 22.89^{\prime} \mathrm{N}, 86^{\circ} 14^{\prime} \mathrm{W}$, approx. $488 \mathrm{~m}, 17$ May $1985, \mathrm{R} / \mathrm{V}$ Citation, Coll. M.K. Wicksten \& B. Cocke, baited bottom trap. Paratypes (LACM type No. 3009): 3 nongravid females, $24.26 \mathrm{~mm}, 26.07 \mathrm{~mm}$, and $26.57 \mathrm{~mm}$, same collection data as holotype. Paratypes (LACM type No. 3010): 2 nongravid females $27.89 \mathrm{~mm}$ and $30.53 \mathrm{~mm}$ long, NW Gulf of Mexico, May 1985, R/V Citation, Coll. M.K. Wicksten. Paratypes (LACM type No. 3011): 3 nongravid females $25.41 \mathrm{~mm}$, $27.23 \mathrm{~mm}$, and $27.38 \mathrm{~mm}$, NE Gulf of Mexico, $28^{\circ} 22.89^{\prime} \mathrm{N}$, 
86²5.20'W, 500-600 m, June 1985, R/V Citation, Coll. M.K. Wicksten and B. Cocke, baited bottom trap. Paratype: 1 nongravid female, $32.67 \mathrm{~mm}$, deposited USNM, same data as LACM 3011. Paratypes: (LACM type No. 3012) 32 females, 2 males $(15.80 \mathrm{~mm}, 18.20 \mathrm{~mm})$, "same general area" as LACM 3011, September, 1986, R/V Citation, Coll. M.K. Wicksten and B. Cocke, baited bottom trap (specimens in poor condition).

Comparative Material Examined. Cirolana (=Politolana) obtusispina: 2 paratypes, SAfM. Cirolana (=Politolana) eximia: 2 syntypes, ZMC; 4 nontype specimens, USNM. Cirolana (=Politolana) impressa: 4 syntypes, MCZ; 1 nontype specimen, MCZ; 2 nontype specimens, USNM. Politolana concharum: 27 nontype specimens, MCZ; 2 nontype specimens, BMNH; 18 nontype specimens, USNM. Politolana polita: 22 nontype specimens, MCZ; 7 nontype specimens, USNM.

Key Diagnostic Characters. Large, length to at least 32.7 $\mathrm{mm}$; body 6-6.5 times longer than broad. Eyes greatly reduced, with or without remnants of cuticular ommatidial facets. Frontal lamina 3-4 times longer than broad, constricted medially, in dorsal view not extended anteriorly beyond basal articles of antennules. Clypeus short and broad, 5-6 times wider than long, wider than labrum. Labrum posterior margin markedly concave. Antennules not reaching posterior margin of cephalon. Antennae not quite reaching posterior margin of pereonite I. Coxal plates not visible in dorsal aspect, but large and distinct in lateral and ventral aspects, III-VII extended beyond posterior margins of their respective segments. Pereopods I-III ischium and merus inner distal margins produced as a scoop-shaped process into which adjacent distal articles collapse. Pleonite 1 entirely covered by pereonite VII. Pleopod 5 endopod of female with large proximal accessory lobe. Pleotelson and uropods with marginal spines and PMS, as figured. Uropod peduncle produced medially, but process shorter than exopod; exopod does not reach endopodal notch; marginal notch of endopod with 1 spine and 1 circumplumose seta; exopod subovate, with 1 large apical spine, 2 spines on inner (medial) margin, and 1 spine on outer (lateral) margin; endopod with 8 apical spines and several blunt outer (lateral) spines near notch. Male appendix masculina arising sub-basally, tapering evenly to the apex.

Description. Body elongate, smooth, 6-6.5 times as long as wide. Large, females to at least $32.7 \mathrm{~mm}$, males to at least $18.2 \mathrm{~mm}$ in length. Eyes reduced; some specimens with remnants of ommatidia and cuticular facets, others without discrete ommatidia or facets and only with scattered subcuticular pigmentation. Faint suture line on dorsal surface of cephalon between frontal margin and eyes (Figure 1).

Frontal lamina 3-4 times longer than broad, constricted medially, barely visible dorsally, projecting between basal articles of antennules but not extended beyond them; clypeus short and very broad, 5-6 times wider than long; labrum broad but narrower than, and weakly immersed in, clypeus, markedly concave on posterior margin (Figures 3c, 5a-c). Antennules and antennae both separated by frontal lamina

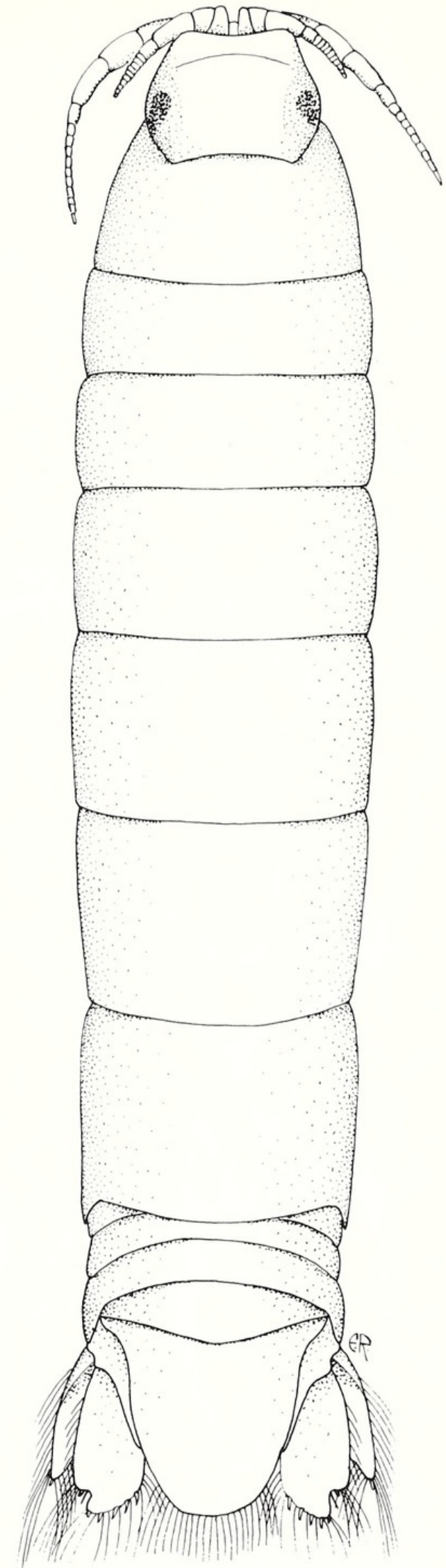

Figure 1. Dorsal view of female holotype (LACM type No. 3008) (setules of PMS on pleotelson and uropods omitted).

Wetzer, Delaney, and Brusca: New deep-water cirolanid isopod 3 


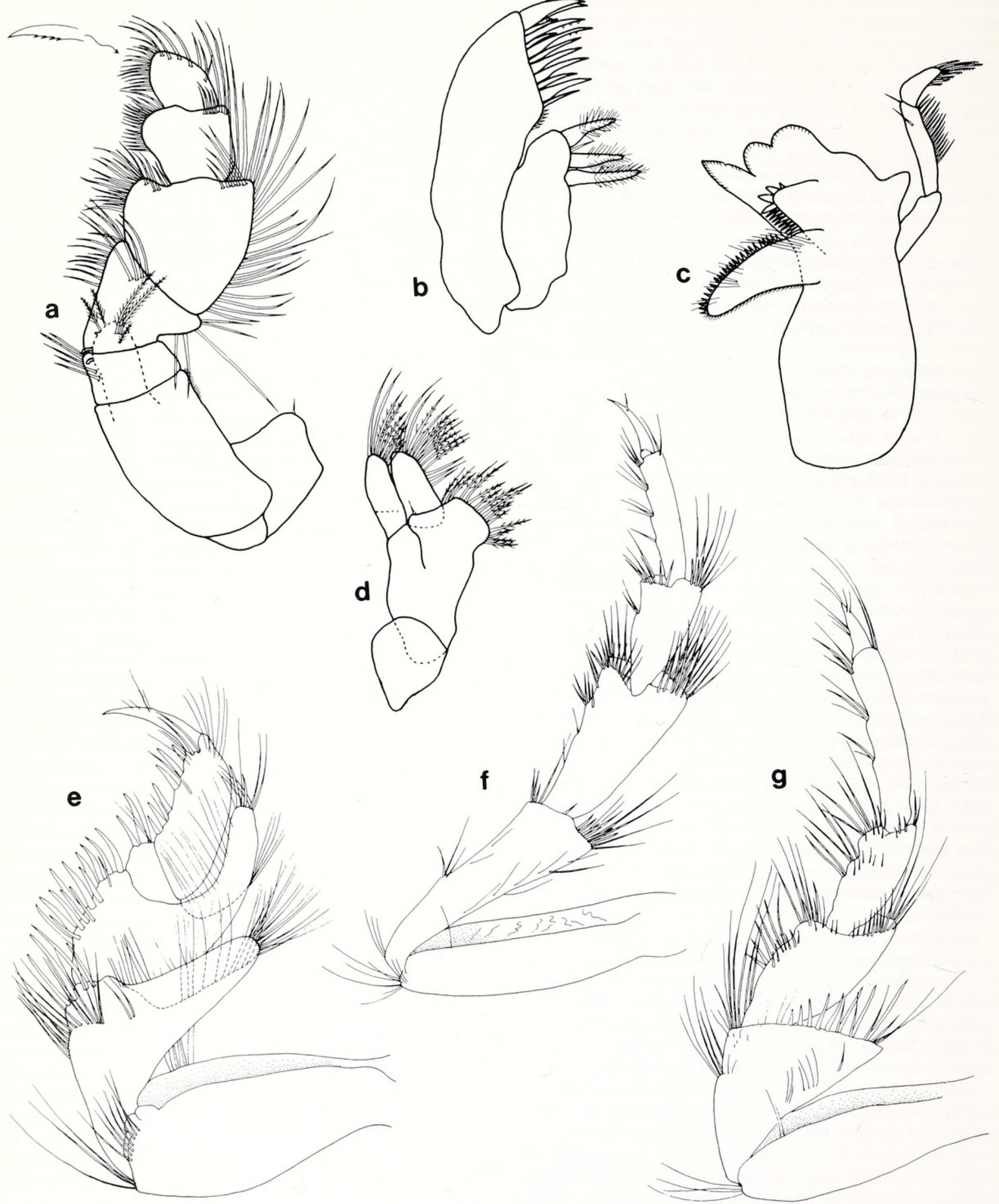

Figure 2. a, maxilliped. b, maxillule. c, right mandible. d, maxilla. e, pereopod I. f, pereopod VII. g, pereopod IV (all from holotype). 


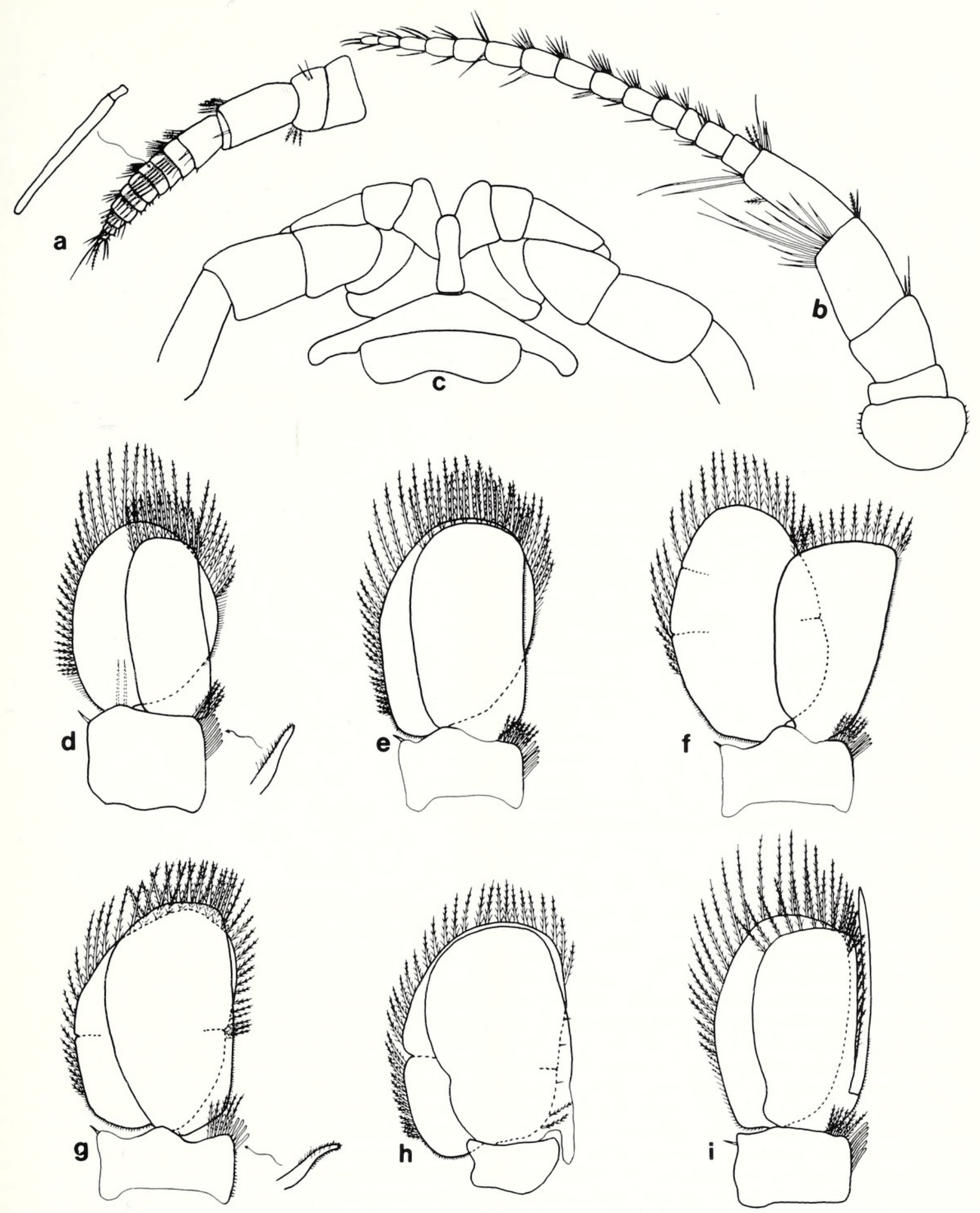

Figure 3. a, antennule. b, antenna. c, frontal lamina, clypeus, and labrum. d, pleopod 1. e, pleopod 2. f, pleopod 3. g, pleopod 4. h, pleopod 5. i, pleopod 2 (male) (a-h from holotype (female); i from male paratype, LACM type No. 3012). 


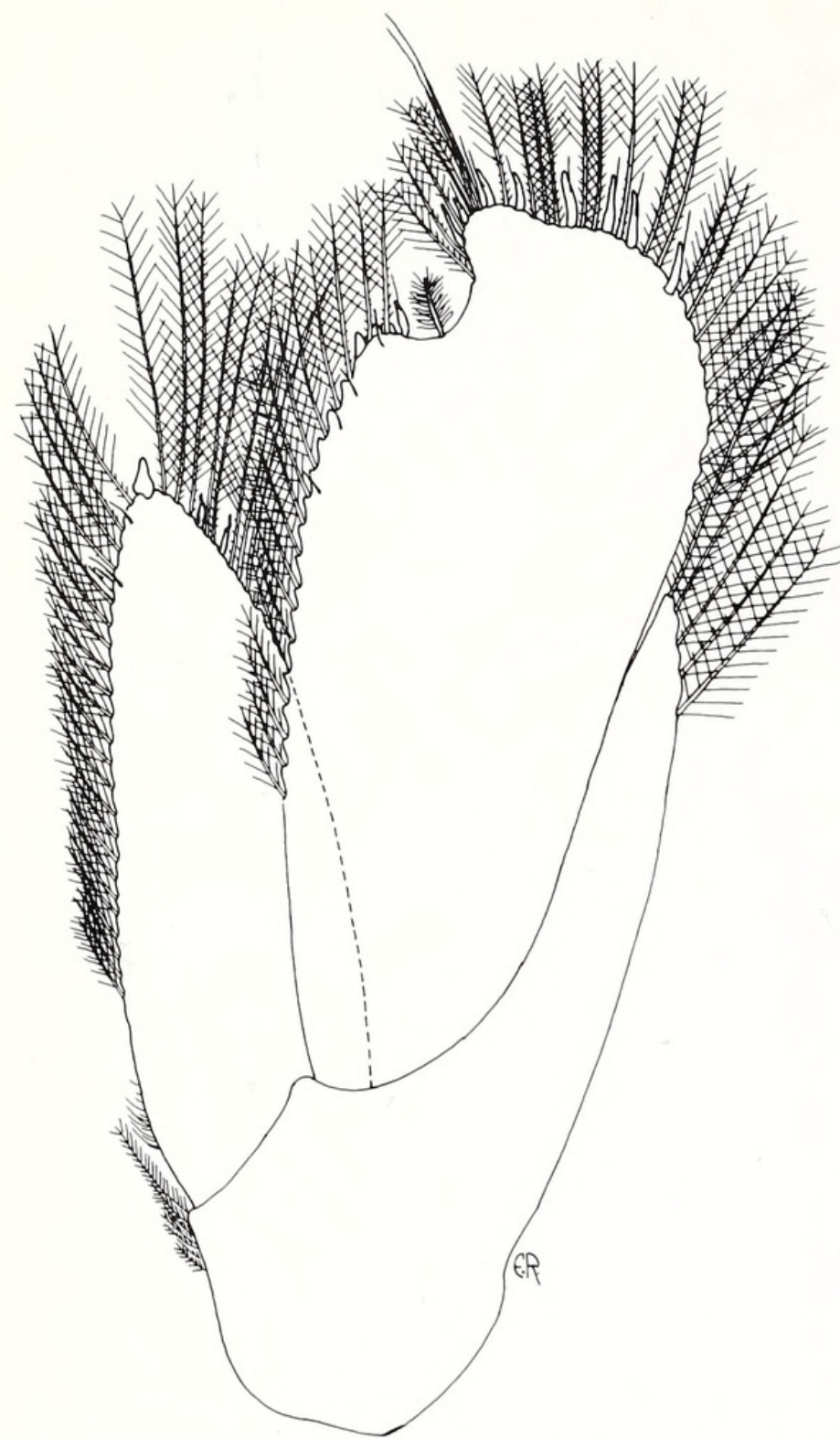

Figure 4. Right uropod, female paratype (LACM type No. 3012).

(Figures 3c, 5a, c). Antennule not reaching posterior margin of cephalon, peduncle of 4 articles, article 4 minute; in dorsal aspect, article 2 appearing to arise at right angle from article 1 , this appearance resulting from sub-triangular shape of first article; flagellum longer than peduncle, with 11 articles (Figure 3a). Antennae not quite reaching posterior margin of pereonite I; flagellum of 10-14 articles (Figure 3b).

Both mandibles with prominent tricuspate incisor process, outer cusp markedly longer than others (Figures 2c, 6a); molar process with short stout spines along upper border, short fine setae on lower border, and numerous long setae on flat surface (Figures 2c, 6c, d); lacinia mobilis well developed, with stout spines (Figures 2c, 6b); distal article of palp with apical pectinate setae; middle article of palp longest, with simple setae (Figure 2c). Maxillule lateral (outer) lobe with 10-13 stout apical spines; medial (inner) lobe with 3 robust, circumplumose spines and $0-1$ smaller spines (Figures $2 b$, 7d). Maxilla with simple and plumose setae (Figures 2d, 7f), as figured. Maxilliped slender; basis elongate, palp 5-articulate, all articles with long setae; endite short with 2 small coupling hooks (Figures 2a, 7a, c).

Pereonites IV-VII considerably longer than pereonites II and III; pereonite VII about $2^{1 / 2}$ times longer than pereonite II. Coxal plates large and compact on pereonites II-VII, not visible in dorsal aspect but distinct and visible in lateral and ventral aspects; coxae increasing in size and acuteness posteriorly, III-VII extending beyond posterior margins of their respective pereonites. Pereopods I-III with abundant long setae, simple and bifid spines; basis concave on medial (inner) margin, receiving ischium; ischium and merus with scoopshaped distal processes into which adjacent distal articles collapse; carpus very short; dactylus slightly curved (Figures 2e, 7e). Basis of pereopods V-VII somewhat concave on medial (inner) margin (as in I-III); with abundant setae of various sizes; dactylus slightly curved (Figures $2 \mathrm{f}, \mathrm{g}$ ).

Pleon comprising 5 free pleonites plus pleotelson, devoid of tubercles and setae. Pleonite 1 completely overlapped by pereonite VII; 1 and 5 narrower than 2-4. Pleotelson with abundant PMS and a few scattered, minute, spines on margin; number of marginal spines uncertain as most are lost in preserved specimens. Uropodal endopod and exopod with PMS and spines as figured (Figure 4); peduncle produced medially but failing to reach apex of exopod; endopod reaching, or barely exceeding pleotelson apex; exopod short, not reaching notch of endopod; exopod slender subovate, never as broad as endopod; lateral (outer) margin of endopod with distal notch containing 1 spine and 1 circumplumose seta; endopod with 8 apical/subapical spines and several blunt outer (lateral) spines near notch; exopod with 1 large apical spine, 2 spines on inner (medial) margin, and 1 spine on outer (lateral) margin (uropodal setae and spines are easily lost in preserved specimens).

Pleopodal rami undivided (Figures 3d-i). Pleopods 1-4 with 4-6 coupling spines on medial margin of peduncle; pleopod 5 without coupling spines, and with proximal accessory lobe on endopod in female; 2-4 with small lobe on medial and lateral margin of peduncle. Male appendix masculina on pleopod 2 arising sub-basally, long and slender, tapering evenly and extending slightly past endopod apex (Figure 3i); penes separate, flattened, long (about as long as ischium or merus of pereopod VII).

Remarks. Of the 44 specimens in the type series, only 2 are males, and these are markedly smaller than all remaining females in the type series. These data suggest the possibility of protandry in this species.

There are now 7 described species of Politolana. All are offshore benthic creatures taken from depths of 35-640 m. At least 1 ( $P$. concharum) has been taken in the water column, indicating that it is capable of swimming. Interestingly, none occur outside the Atlantic Ocean. All previously described North American species have been reported only from the New England coast. The genus now includes: $P$. wickstenae new species, northern Gulf of Mexico; P. polita (Stimpson, 1853), NW Atlantic (Bay of Fundy to Massachusetts); $P$. 

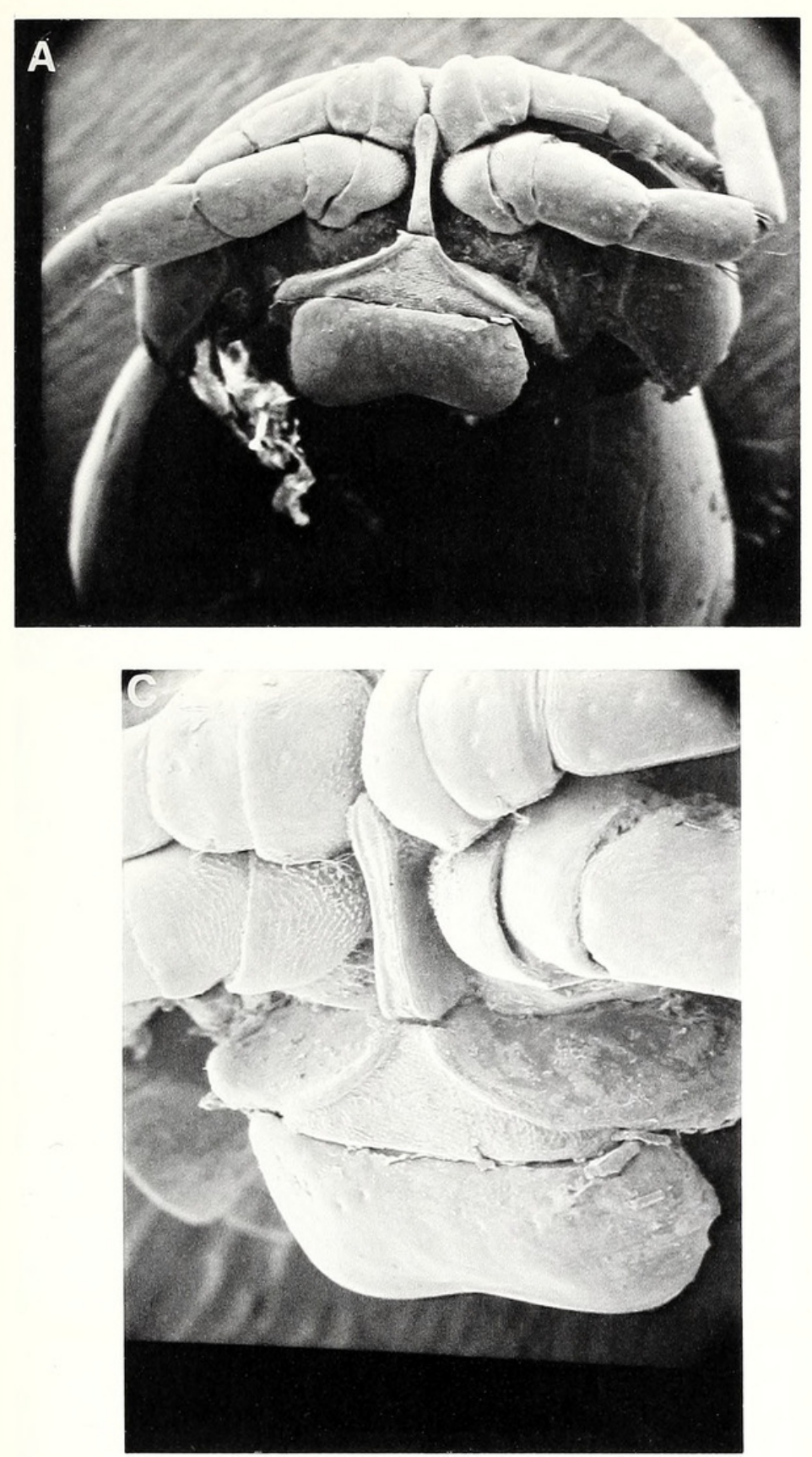

Figure 5. Scanning electron micrographs of female paratype (LACM type No. 3011). a, ventral view of antennules, antennae, frontal lamina, clypeus, and labrum $(25 \times)$. b, ventral view of clypeus and labrum $(55 \times)$. c, ventrolateral view of antennules, antennae, frontal lamina, clypeus, and labrum $(50 \times)$.

concharum (Stimpson, 1853), NW Atlantic (Nova Scotia to South Carolina); P. impressa (Harger, 1883), NW Atlantic (Maryland to New Jersey); P. eximia (Hansen, 1890), Brazil; P. micropthalma (Hoek, 1882), Europe; and P. obtusispina (Kensley, 1975), South Africa. As Bruce (1981) pointed out, species in this genus are all very similar to one another. None of the 6 previously described species has been adequately diagnosed or figured, and types were not designated for any but Kensley's South African P. obtusispina. The type species $(P$. polita $)$ has never been properly described. When Stimp-

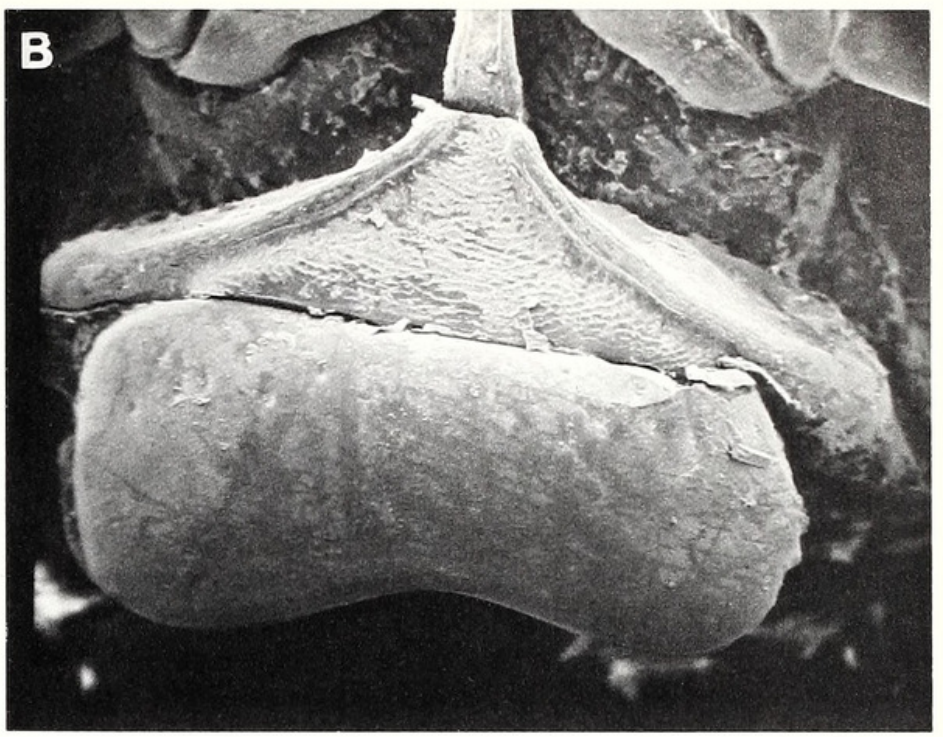

son (1853) erected $P$. concharum he did not actually describe it, but simply compared it as an addendum to his description of $P$. polita. The best available descriptions of the 3 previously described North American species are those of Harger (1883), although it is not clear whether Harger utilized type material in his study. Richardson (1905) and Kussakin (1979) apparently based their interpretations of these species on Harger's descriptions. There have been no subsequent studies of the North American Politolana. Two of us (RCB \& RW) are currently undertaking a phylogenetic and biogeographic study of this genus.

Politolana wickstenae is easily differentiated from all other known species of Politolana by its short ovate uropodal exopods, which fail to reach the endopodal notch, the uniformly slender appendix masculina of males, the evenly convex pleotelson margin, the compactness of the coxae (not visible in dorsal aspect), and the unique spination of the legs and uropods. Politolana wickstenae closely resembles $P$. polita and $P$. impressa. However, these species differ in shape, setation, and spination of the leg articles, pleotelson, and uropod spination, and the relative length and shape of the uropodal lamellae (see Harger, 1883 for comparisons). The uropods of $P$. polita and $P$. impressa differ from those of $P$. wickstenae in having long, narrow, scimitar-like exopods that are about the same length as the inner process of the peduncle, extending at least to or beyond the endopodal notch. In $P$. wickstenae the exopod is sub-acutely ovate and shorter, and never extends to the endopodal notch. Other, more subtle differences exist between these species, such as: the body of $P$. polita is more robust and deeper (in the dorsoventral plane) than that of $P$. wickstenae; the frontal lamina of $P$. polita is extremely narrow, but manifestly expanded at its anterior end; the proximal articles of the antennule peduncles of $P$. polita are so close together as to be touching each other (this close approximation is rare in $P$. wickstenae); and the lateral (outer) lobe of the peduncle of pleopods $2-4$ is large in $P$. impressa, markedly expanded distally (in $P$. wickstenae this lobe is small, and primarily expanded proximally). 

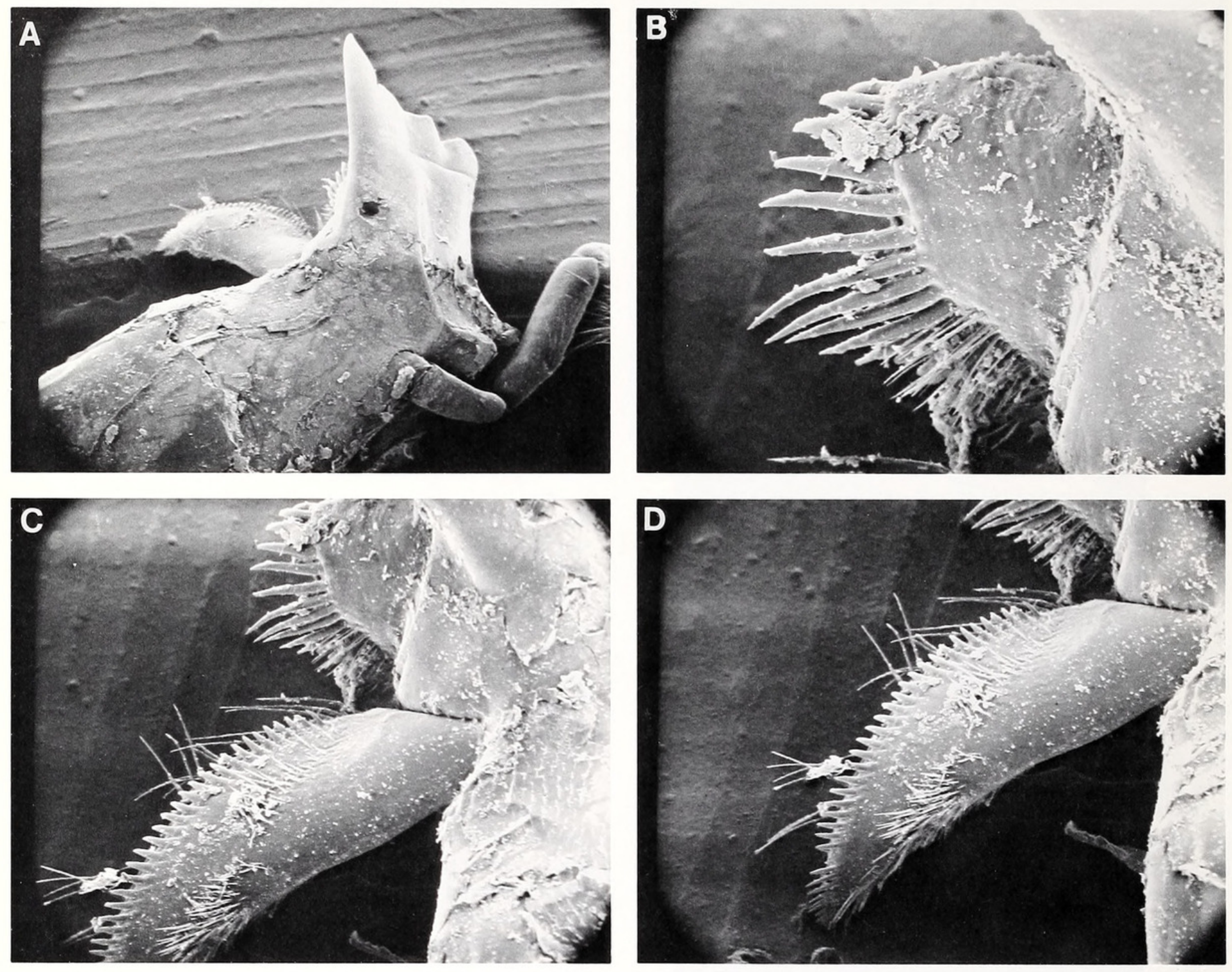

Figure 6. Scanning electron micrographs of female paratype (LACM type No. 3011$)$. a, mandible $(50 \times)$. b, lacinia mobilis $(200 \times)$. c, molar process and lacinia mobilis $(100 \times)$. d, molar process $(100 \times)$.

Etymology. Politolina wickstenae is named for M.K. Wicksten, crustacean biologist and professor of marine biology at Texas A\&M University who, along with B. Cocke, collected the type material of this species.

Distribution. Gulf of Mexico; so far known only from the vicinity of $28^{\circ} \mathrm{N}, 86^{\circ} \mathrm{W}$.

\section{ACKNOWLEDGMENTS}

The authors wish to thank T. Bowman, N. Bruce, B. Kensley, and B. Wilson for their very helpful reviews of the manuscript. This study was supported by a National Science Foundation Grant to R.C. Brusca (BSR-85-14093).

\section{LITERATURE CITED}

Botosaneanu, L., N. Bruce, and J. Notenboom. 1986. Isopoda: Cirolanidae. Pp. 412-422. In: L. Botosaneanu (ed.). Stygofauna Mundi. E. J. Brill, Leiden.
Bruce, N.L. 1981. Cirolanidae (Crustacea: Isopoda) of Australia: diagnoses of Cirolana Leach, Metacirolana Nierstrasz, Neocirolana Hale, Anopsilana Paulian \& Debouteville, and three new genera-Natatolana, Politolana and Cartetolana. Australian Journal of Marine and Freshwater Research, 32:945-966.

-1 1986. Cirolanidae (Crustacea: Isopoda) of Australia. Records of the Australian Museum, Supplement No. 6:1-239.

Harger, O. 1883. Reports on the results of dredging, under the supervision of Alexander Agassiz, on the east coast of the United States during the summer of 1880 , by the U.S. Coast survey Steamer "Blake," Commander J.R. Bartlett, U.S.N., commanding. XXIII. Report on the Isopoda. Bulletin, Museum of Comparative Zoology, Harvard, 11(4):91-104.

Kussakin, O. 1979. Marine and brackish-water Isopoda of 

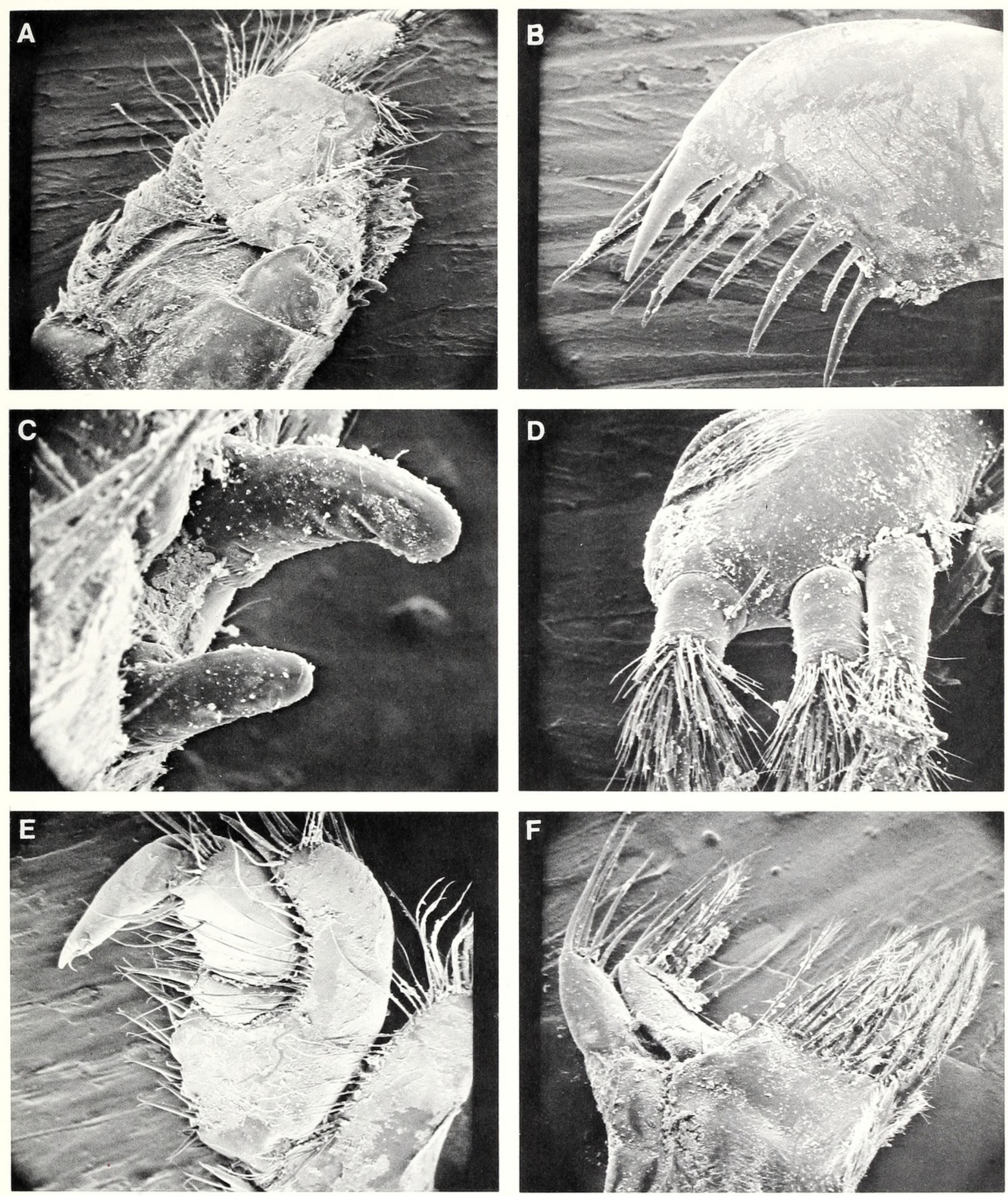

Figure 7. Scanning electron micrographs of female paratype (LACM type No. 3011$)$. a, maxilliped (50×). b, maxillule, lateral lobe ( $100 \times$ ). c, coupling hooks on maxillipedal endite $(500 \times)$. d, maxillule, medial lobe $(200 \times)$. e, pereopod I, distal articles $(50 \times)$. f, maxilla $(100 \times)$. 
cold and temperate waters of the Northern Hemisphere. Flabellifera. Opredeliteli po faune SSSR, Akad. Nauk SSSR [Academy of Sciences, USSR, Zoology], No. 122. 472 pp. [in Russian]

Monod, T. 1930. Contribution à l'étude des "Cirolanidae." Annales de Sciences Naturelles, Zoologie, 13:129-183.

Richardson, H.S. 1905. A monograph on the isopods of
North America. Bulletin United States National Museum, 54:1-727.

Stimpson, W. 1853. Synopsis of the marine Invertebrata of Grand Manan. Smithsonian Contributions to Knowledge, 16:39-44.

Submitted 28 July 1986; accepted 2 March 1987. 


\section{$2 \mathrm{BHL}$ Biodiversity Heritage Library}

Wetzer, Regina, Delaney, Paul M., and Brusca, Richard C. 1987. "Politolana wickstenae new species, a new cirolanid isopod from the Gulf of Mexico, and a review of the 'Conilera genus-group' of Bruce (1986)." Contributions in science 392, 1-10. https://doi.org/10.5962/p.226825.

View This Item Online: https://www.biodiversitylibrary.org/item/216729

DOI: https://doi.org/10.5962/p.226825

Permalink: https://www.biodiversitylibrary.org/partpdf/226825

\section{Holding Institution}

Smithsonian Libraries

\section{Sponsored by}

Biodiversity Heritage Library

\section{Copyright \& Reuse}

Copyright Status: In Copyright. Digitized with the permission of the rights holder

Rights Holder: Natural History Museum of Los Angeles County

License: https://creativecommons.org/licenses/by-nc-sa/4.0/

Rights: https://www.biodiversitylibrary.org/permissions/

This document was created from content at the Biodiversity Heritage Library, the world's largest open access digital library for biodiversity literature and archives. Visit BHL at https://www.biodiversitylibrary.org. 